\title{
MEKANISME PERAMPASAN ASET DENGAN MENGGUNAKAN NON-CONVICTION BASED ASSET FORFEITURE SEBAGAI UPAYA PENGEMBALIAN KERUGIAN NEGARA AKIBAT TINDAK PIDANA KORUPSI
}

\author{
Sudarto \\ Email: sudarto046@gmail.com \\ Mahasiswa Magister Ilmu Hukum Fakultas Hukum UNS Surakarta \\ Hari Purwadi, Hartiwiningsih \\ Email: hpurwadie@staff.uns.ac.id, hartiwi@yahoo.com \\ Dosen Fakultas Hukum UNS Surakarta
}

\begin{abstract}
This article aims to determine the mechanism confiscation of assets without punishment or Non-Conviction Based (NCB) Assets forfeiture as an alternative in efforts to restore assets to corruption as an answer to the problems the difficulty plunder the wealth perpetrators of corruption that has changed hands, change shape, or hidden. This article uses the normative research using primary materials that are authoritative, in the form of primary legal materials and secondary law. This article explains that the mechanism of expropriation of assets without punishment in the future can be set in legislation expropriation of assets by a mechanism in accordance with the provisions of United Nations Convention Against Corruption, which allows the application of inverted authentication by the perpetrators of corruption since the investigation stage in order to realize the principle of follow the money in the eradication of corruption.
\end{abstract}

Keywords: Confiscation of Assets, NCB, Corruption.

\begin{abstract}
Abstrak
Artikel ini bertujuan untuk mengetahui mekanisme perampasan aset tanpa pemidanaan atau NonConviction Based (NCB) Assets Forfeiture sebagai alternatif dalam upaya mengembalikan aset hasil tindak pidana korupsi sebagai jawaban permasalahan sulitnya melakukan perampasan harta kekayaan pelaku tindak pidana korupsi yang telah berpindah tangan, berubah wujud, atau disembunyikan. Artikel ini menggunakan penelitian normatif dengan menggunakan bahan primer yang bersifat otoritatif, berupa bahan hukum primer dan bahan hukum sekunder. Artikel ini menjelaskan bahwa mekanisme perampasan aset tanpa pemidanaan dimasa mendatang dapat diatur dalam undang-undang perampasan aset dengan mekanisme yang sesuai dengan ketentuan United Nations Convention Against Corruption, yang memungkinkan penerapan pembuktian terbalik oleh pelaku tindak pidana korupsi sejak tahap penyidikan demi terwujudnya prinsip follow the money dalam pemberantasan tindak pidana korupsi.
\end{abstract}

Kata Kunci : Perampasan Aset, NCB, Korupsi.

\section{A. Pendahuluan}

Korupsi adalah perbuatan kejahatan yang keji yang merugikan keuangan negara dan perekonomian negara dan pada akhirnya menyengsarakan rakyat. Korupsi dikategorikan sebagai salah satu kejahatan terorganisasi dan bersifat transnasional karena modus operandi korupsi yang telah menyatu dengan sistem birokrasi (Asep Warlan Yusuf, 2013). S etiap tahun data penanganan perkara tindak pidana korupsi di Indonesia terus meningkat, namun hal itu terlihat belum mampu menurunkan crime rate korupsi, dan lebih jauh lagi belum mampu memunculkan daya tangkal dan daya jera bagi para pelaku korupsi (http://www.bedanews.com/prof-dr-h-dwidja-priyatnousul kan-amandemen-uuptpk, diaks es pada tanggal 31 Agustus 2016 pukul 09.00 WIB.).

Temuan Transparansi Internasional, Indeks Persepsi Korupsi (Corruption Perception Index/ CPI) tahun 2015, Indonesia mencapai skor 36. J umlah tersebut meningkat 2 (dua) poin dibanding skor CPI tahun 2014 yaitu 34. Dengan skor tersebut, peringkat korupsi Indonesia turun dari peringkat 107 ke peringkat 88, dari 168 negara (http://nasional.kompas.com/read/2016/ 01/27/15053181/I ndeks. Persepsi.Konupsi. Indonesia. 
Membaik, diakses pada tanggal 16 September 2016 Pukul 16.30 WIB.).

Keahlian para koruptor menyembunyikan dan menyamarkan hasil kejahatannya tidak saja di dalam negeri, tetapi sudah bersifat transnasional yang melampaui batas wilayah negara yang menyulitkan aparat penegak hukum dalam melacak dan memulihkan keuangan negara akibat tindak pidana korupsi (ST Burhanuddin, 2013). Aset hasil tindak pidana korupsi yang diambil oleh para koruptor banyak yang dilarikan serta disembunyikan di luar negeri dengan cara disembunyikan di rekening bank sehingga upaya melacak serta mengembalikan aset tersebut menjadi sulit. Ringannya sanksi hukum yang selama ini diterapkan kepada pelaku tindak pidana korupsi, hanya dikenakan sanksi pidana penjara badan beberapa tahun dan tidak ada keharusan mengembalikan harta yang mereka korup. Hal tersebut dikarenakan para pelaku tindak pidana korupsi dengan pintarnya bisa mengatasnamakan keluarganya atas aset yang mereka peroleh dari tindak pidana korupsi. Sanksi yang demikian ringan tidak membuat para pelaku tindak pidana korupsi merasa jera, bahkan setelah bebas dari penjara mereka bisa menikmati harta milyaran yang mereka korupsi.

Terdakwa korupsi juga tidak sedikit yang bebas oleh karena kurangnya alat bukti yang dipergunakan untuk membuktikan perbuatan korupsinya secara materiil terhadap tindak pidana korupsi yang merupakan tindak pidana formiil, dan asset yang dimilikinya juga tidak dapat dirampas oleh negara. Hal ini sangatlah ironis, dikarenakan tujuan untuk memulihkan keuangan negara dari pemberantasan tindak pidana korupsi tidak tercapai, baik memidanakan pelaku dan merampas aset yang diperolehnya dari tindak pidana korupsi.

Nilai kerugian negara akibat tindak pidana korupsi di Indonesia selama tahun 2001 2015 mencapai Rp 203,9 triliun. Hasil kajian Laboratorium IImu Ekonomi Universitas Gadjah Mada (UGM), juga menghitung hukuman berupa denda dan sita aset hanya terkumpul Rp 21,26 triliun (https://beritagar.id/artikel/berita/kerugiannegara-akibat-konupsi-di-indonesia-rp2039-triliun/, diakses tanggal 29 November 2016 Pukul 09.00 WIB.). Berdasarkan data di atas, jelas bahwa selain memidanakan pelaku tindak pidana korupsi, perampasan aset untuk mengembalikan kerugian negara belum maksimal. Perbandingan antara kerugian negara secara keseluruhan dan yang dapat dirampas adalah tidak seimbang.
Berdasarkan urutan latar belakang yang sudah dipaparkan di atas, agar permasalahan yang akan diteliti menjadi jelas dan penelitian hukum mencapai tujuan yang diinginkan, maka permasalahan yang akan dibahas dalam penelitian ini adalah sebagai berikut:

1. Apakah model perampasan aset dengan menggunakan Non-Conviction Based (NCB) Asset Forfeiture memiliki potensi lebih maksimal dalam upaya pengembalian kerugian negara akibat tindak pidana korupsi?

2. Bagaimana model perampasan aset dengan menggunakan Non-Conviction Based (NCB) Asset F orfeiture yang sesuai dengan sistem peradilan di Indonesia?

\section{B. Metode Penelitian}

J enis Penelitian ini adalah penelitian hukum normatif atau penelitian hukum doktrinal. Penelitian ini menggunakan pendekatan konseptual, menggunakan teknik analisis bahan hukum deduktif silogisme dengan menggunakan premis minor dan premis mayor dan penarikan kesimpulan. Penelitian ini menggunakan teknik analisis bahan hukum studi kepustakaan atau library research.

\section{Hasil Penelitian dan Pembahasan}

1. Perampasan aset dengan menggunakan Non-Conviction Based (NCB) Asset F orfeiture sebagai upaya pengembalian kerugian negara akibat tindak pidana korupsi

Perampasanasettanpa pemidanaan (NonConviction Based Asset Forfeiture) adalah mekanisme hukum yang memungkinkan aset milik negara yang telah diambil oleh pelaku kejahatan dimungkinkan untuk dirampas kembali. Konsep ini merupakan bagian dari United Nations Convention Against Corruption, 2003 (Konvensi PBB Menentang Korupsi, 2003) yang telah diratifikasi oleh pemerintah Indonesia, konsekuensinya Indonesia sebagai negara hukum yang bercirikan salah satunya adalah tindakan negara harus didasarkan pada hukum yang telah dibuat secara demokratis sebelumnya, sehingga hukum yang dibuat itu memiliki supremasi atau berada di atas segalanya, dan semua orang berkedudukan sama dihadapan hukum.

Perampasan aset yang berlaku di Indonesia saat ini dapat dilaksanakan semata-mata terbatas hanya jika pelaku 
kejahatan telah dinyatakan terbukti secara sah dan menyakinkan bersalah melakukan tindak pidana oleh putusan pengadilan yang telah berkekuatan hukum tetap (inckracht) atau dengan kata lain perampasan aset dilakukan dengan putusan pidana, namun perampasan pidana mengalami banyak kesulitan dalam pelaksanaannya. Salah satunya adalah adanya kemampuan dari pelaku untuk mengalihkan atau melarikan hasil kejahatan maupun instrument kejahatan ke luar negeri dan bahkan pelakunya bisa saja melarikan diri ke luar negeri dan tidak dapat diekstradisi kembali ke Indonesia. Sebagai contoh kasus korupsi dengan terdakwa Djoko S. Candra atau bahkan kasus yang paling menghebohkan dalam sejarah pemberantasan korupsi di Indonesia yaitu kasus korupsi Edy Tansil. Mereka raib seperti ditelan bumi, bahkan sekalipun keberadaannya diketahui namun tidak bisa dieksekusi oleh pemerintah karena berbagai keterbatasan diplomatik. Padahal aset/harta kekayaan mereka masih ada di Indonesia bahkan mereka masih bisa memperoleh keuntungan dari bergeraknya usahausaha mereka yang berada di Indonesia, sedangkan pemerintah Indonesia tidak bisa menjangkaunya. Untuk itu dipandang perlu memiliki instrument hukum yang memiliki sistem perampasan yang memungkinkan dilakukannya perampasan aset hasil tindak pidana melalui mekanisme yang dikenal dengan Non-Conviction Based (NCB) Asset Forfeiture. Mekanisme ini menekankan perampasan aset tindak pidana secara "in rem" dan bukan kepada orangnya (in personam). Dengan demikian putusan yang telah berkekuatan hukum tetap terhadap pelaku kejahatan bukan merupakan prasyarat yang harus dipenuhi dalam perampasan aset.

Non-Conviction Based Asset Forfeiture merupakan cara untuk melakukan perampasan aset hasil kejahatan. Dalam sistem common law ada dikenal dua jenis perampasan aset yang berkembang, yaitu: (Muhhamad Yusuf, 2010 : 616-617).

a. Ordinary common law forfeiture (perampasan yang berlaku berdasarkan putusan pengadilan), dan;

b. Statutory forfeiture (perampasan yang berlaku berdasarkan undang-undang).

Ordinary common law forfeiture terjadi setelah adanya putusan pengadilan atas kejahatan serius. Tindakan perampasan dipandang oleh pihak otoritas yang berwenang sebagai sebuah konsekuensi dari pidana tersebut. Ordinary common law forfeiture menjadi perampasan in personam, sehingga perampasan dapat dilakukan kepada semua property yang nyata dan pribadi yang dimiliki terpidana setelah diputuskan oleh putusan pengadilan. Sedangkan statutory forfeiture merupakan perampasan yang sebaliknya yaitu diberlakukan tanpa membutuhkan adanya putusan pengadilan, akan tetapi hanya terbatas kepada property yang digunakan dalam melakukan kejahatan statutory forfeiture disebut dengan perampasan in rem perdata. Konsepnya yang bersalah adalah property bukan orang.

Menurut Fletcher N. Baldwin, J r. model civil forfeiture menjadi signifikan untuk pengembalian hasil korupsi di Indonesia karena civil forfeiture menggunakan pembalikan beban pembuktian dan dapat melakukan penyitaan lebih cepat setelah diduga adanya hubungan aset dengan tindak pidana. Selain itu civil forfeiture merupakan gugatan terhadap aset bukan kepada terdakwa atau kepada tersangka, sehingga aset negara dapat diselamatkan meski pelaku telah meninggal atau meninggal dunia (Muhammad Yusuf, 2010 : 617).

Perampasan aset tanpa pemidanaan merupakan mekanisme perampasan yang komprehensif, karena dimulai dari penelusuran, pemblokiran, dan penyitaan, serta proses persidangan di pengadilan. Non-Conviction Based Asset Forfeiture dapat berjalan dengan efektif apabila terdapat kemauan yang kuat dari Kejaksaan Agung untuk mengajukan permohonan perampasan aset ke pengadilan. Komitmen tersebut juga harus ada dari pengadilan dalam hal ini hakim dalam memeriksa dan mengadili permohonan Non-Conviction Based Asset Forfeiture dengan tidak terpengaruh pada pendapat yang menyatakan bahwa proses Non-Conviction Based Asset Forfeiture itu melanggar Hak Asasi Manusia.

Penerapan pembalikan beban pembuktian dalam mekanisme NonConviction Based Asset Forfeiture bukan sesuatu yang harus dipermasalahkan dan bahkan tidak melanggar Hak Asasi Manusia, karena menurut beliau pembalikan beban pembuktian (reversal of the burden of 
proof) dalam tindakan Non-Conviction Based Asset Forfeiture tidak ada kaitannya dengan azas "siapa yang menuduh dialah yang harus membuktikan tuduhannya" dan tidak berkaitan dengan asas "praduga tak bersalah". Alasannya adalah kedua asas tersebut berhubungan dengan pembuktian akan kesalahan seorang terdakwa di persidangan, sedangkan pembalikan beban pembuktian adalah suatu bentuk atau cara menunjukkan sah atau tidaknya kepemilikian atas suatu aset/harta kekayaan dan menjelaskan bagaimana cara pelaku kejahatan memperoleh kepemilikannya itu.

Dengan ketidakmampuan dari pelaku membuktikan bahwa dia telah memiliki harta kekayaan tersebut secara sah menurut hukum, maka telah ada dugaan kuat bahwa harta tersebut merupakan hasil kejahatan. Harta kekayaan yang tidak dapat dibuktikan tersebutlah yang kemudian harus dinyatakan sebagai "harta kekayaan yang tercemar" (legally tainted property) oleh pengadilan (Hakim). Oleh karena telah dinyatakan sebagai harta kekayaan yang tercemar oleh Pengadilan, maka J aksa Pengacara Negara kemudian mengajukan permohonan agar supaya harta yang tercemar tersebut untuk dinyatakan sebagai milik negara.

Cara yang paling tepat dan sederhana dalam melakukan mekanisme Non-Conviction Based (NCB) Asset Forfeiture adalah pada awalnya harta yang diduga merupakan hasil kejahatan dilakukan pemblokiran dan ditarik dari lalu lintas perekonomian yaitu melalui penyitaan yang dimintakan kepada Pengadilan. Selanjutnya harta tersebut dinyatakan sebagai harta tercemar dengan penetapan pengadilan. Setelah dinyatakan sebagai harta tercemar, pengadilan lalu melakukan pengumuman melalui media yang dapat diakses dan diketahui oleh orang banyak selama waktu yang cukup yaitu kurang lebih 30 (tiga puluh) hari. J angka waktu tersebut dipandang cukup bagi para pihak ketiga untuk dapat mengetahui bahwa akan dilakukan perampasan aset oleh pengadilan. Apabila dalam jangka waktu tersebut ada pihak ketiga yang merasa keberatan dengan tindakan perampasan, maka pihak ketiga tersebut dapat mengajukan perlawanan ke pengadilan dan membuktikan dengan alat bukti yang sah bahwa dialah pemilik harta tersebut dengan menjelaskan bagaimana perolehan harta tersebut (Yenti Garnasih, 2010 : 630).

Dengan demikian menurut peneliti mekanisme Non-Conviction Based Asset Forfeiture merupakan cara yang efektif untuk membuat kejahatan tersebut menjadi "tidak menguntungkan" karena pelakunya akan berpikir kembali mengenai akibat yang akan timbul nantinya. Bagi Penulis, konsep Non-Conviction Based Asset F orfeiture telah menjadi kebutuhan hukum di Indonesia karena mekanisme Non-Conviction Based Asset Forfeiture menjadi alternatif untuk memperoleh kembali kekayaan negara yang hilang karena tindak pidana yang berkaitan dengan perekonomian negara.

2. Model Perampasan Aset menggunakan Non-Conviction Based Asset Forfeiture yang sesuai dengan S istem Peradilan di Indonesia.

Dalam sistem hukum di Indonesia, perampasan aset merupakan bagian dari pidana tambahan berupa perampasan barang-barang tertentu hasil tindak pidana. $\mathrm{Hal}$ ini berlaku umum bagi setiap tindak pidana yang terjadi dalam ranah hukum pidana di Indonesia dengan tujuan merugikan terpidana yang terbukti melalui putusan pengadilan yang mengikat telah melakukan tindak pidana sehinga tidak dapat menikmati hasil tindak pidana. Konsekuensi dari pidana tambahan adalah bahwa pidana tambahan tidak dapat berdiri sendiri dan selalu mengikuti perkara pokok, artinya pidana tambahan hanya dapat dijatuhkan bersamaan dengan pidana pokok. Perampasan aset hasil kejahatan hanya dapat dilakukan apabila perkara pokok diperiksa dan terdakwa terbukti bersalah maka barang yang didapatkan dari hasil kejahatan, oleh pengadilan dapat ditetapkan agar dirampas oleh negara untuk dimusnahkan dilakukan tindakan lain agar barang atau aset tersebut dapat digunakan untuk kepentingan negara dengan cara menghibahkannya atau melakukan lelang atas aset hasil tindak pidana.

Dalam ketentuan yang ada dalam hukum pidana di Indonesia, perampasan akan barang tertentu hanya dapat dilakukan dengan putusan pengadilan yang memiliki kekuatan hukum mengikat. Dengan demikian selama proses penegakan hukum atas sebuah tindak pidana dapat dilakukan tindakan lain yaitu penyitaan. Penyitaan merupakan upaya paksa yang dilakukan oleh 
penyidik untuk mengambil alih dan meyimpan benda (aset) untuk kepentingan pembuktian dalam proses penegakan hukum baik pada tahapan penyidikan, penuntutan, dan persidangan. Hal tersebutbersifat sementara yang hanya dapat dilakukan dengan ijin dari ketua pengadilan negeri setempat, namun dalam keadaan mendesak dapat dilakukan penyitaan terlebih dahulu baru kemudian penyitaan yang telah terjadi dilaporkan pada ketua pengadilan negeri setempat guna mendapatkan persetujuan.

Ketentuan lebih lanjut mengenai penyitaan terdapat pada Pasal 39 KUHAP, yang mengatur mengenai ketentuan barangbarang yang dapat dikenakan penyitaan. Barang-barang tersebut adalah benda atau tagihan tersangka atau terdakwa yang seluruh atau sebagai diduga diperoleh dari tindak pidana atau sebagian hasil dari tindak pidana; benda yang telah dipergunakan secara langsung untuk melakukan tindak pidana atau untuk mempersiapkannya; benda yang dipergunakan untuk menghalanghalangi penyelidikan tindak pidana;benda yang khusus dibuatatau diperuntukkan melakukan tindak pidana; benda lain yang mempunyai hubungan langsung dengan tindak pidana yang dilakukan. KUHAP juga membatasi benda yang dapat disita, yaitu hanya pada benda yang memiliki keterkaitan secara langsung dengan tindak pidana, bendabenda yang tidak terkait secara langsung dengan terjadinya sebuah peristiwa pidana tidak dapat disita oleh penyidik. Dalam hal tertangkap tangan, penyidik dapat melakukan penyitaan terhadap benda dan alatyang patut diduga telah digunakan untuk melakukan tindak pidana sebagai barang bukti.

Benda sitaan dapat dikembalikan kepada orang yang paling berhak ketika penyidikan dan penuntutan tidak memerlukan benda sitaan tersebut. Selain itu barang sitaan juga dapat dikembalikan ketika peristiwa yang terjadi tidak jadi dituntut karena dinyatakan tidak cukup bukti dan dinyatakan bukan tindak pidana. Kondisi lain dimana barang sitaan dapat dikembalikan adalah ketika terjadi pengesampingan perkara demi kepentingan umum atau perkara tersebut ditutup demi hukum, kecuali apabila benda itu diperoleh dari suatu tindak pidana atau yang dipergunakan untuk melakukan suatu tindak pidana.
Ketika perkara yang dimaksud sudah diputus oleh hakim maka benda yang dikenakan penyitaan dikembalikan kepada orang atau pihak yang disebut dalam putusan ters ebut, kecuali jika menurut putusan hakim, benda itu dirampas untuk negara, baik untuk dimusnahkan atau untuk dirusak sampai tidak dapat dipergunakan lagi, atau dilelang untuk kepentingan kas negara dan dapatjuga digunakan untuk kepentingan pembuktian dalam perkara lain.

Dengan menggunakan mekanisme ini, maka perampasan aset hasil tindak pidana tidak maksimal karena benda yang dapat disita dan dirampas hanya benda yang memiliki keterkaitan langsung dengan sebuah tindak pidana. Hal ini menjadi kendala bagi aparat penegak hukum yang melakukan penyitaan atau perampasan karena memilah barang mana saja yang berkaitan langsung atau barang mana yang tidak memiliki kaitan langsung dengan tindak pidana membutuhkan waktu sedangkan sifat dari penyitaan dan perampasan aset membutuhkan kecepatan agar aset yang ada tidak berpindah tangan.

Dengan menggunakan mekanisme yang ada dalam KUHAP, praktek perampasan aset hasil tindak pidana membutuhkan waktu yang sangat lama, karena waktu yang dibutuhkan untuk sebuah perkara sampai memperoleh putusan pengadilan yang berkekuatan mengikat bisa menghabiskan waktu berbulan-bulan bahkan mungkin dalam hitungan tahun. Panjangnya waktu yang dibutuhkan, memudahkan terdakwa untuk menyembunyikan aset yang didapatkan dan digunakannya dalam tindak pidana sehingga tujuan awal dari perampasan aset, yaitu merampas hasil kejahatan sehingga pelaku tidak dapat menikmati kekayaan yang bukan menjadi haknya tidak tercapai karena pelaku sudah melakukan upaya untuk melarikan aset tersebut.

Mekanisme perampasan aset seperti yang tercantum dalam KUHAP seperti yang telah dijelaskan di atas, menitik beratkan pada pengungkapan tindak pidana, yang di dalamnya terdapatunsur menemukan pelaku dan menempatkan pelaku dalam penjara dan hanya menempatkan perampasan aset sebagai pidana tambahan ternyata belum cukup efektif untuk menekan angka kejahatan. Dengan tidak menjadikan perampasan aset sebagai fokus dari penegakan hukum 
atas tindak pidana yang memiliki unsur ekonomi maka terjadi pembiaran terhadap pelaku tindak pidana untuk menguasai dan menikmati hasil tindak pidana bahkan melakukan pengulangan atas tindak pidana yang pernah dilakukannya bahkan dengan modus operandi yang lebih canggih.

Adanya mekanisme subsider atas kewajiban pembayaran aset hasil tindak pidana juga menyebabkan upaya perampasan aset hasil tindak pidana menjadi kurang efektif. Sebab sebagian besar terpidana akan lebih memilih untuk menyatakan ketidaksanggupannya mengembalikan aset yang dihasilkan dari tindak pidana yang telah dilakukannya sehingga ketidaksanggupannya tersebut akan diganjar dengan kurungan badan sebagai pengganti. Adanya mekanisme subsider yang lamanya tidak melebihi ancaman hukuman pidana pokoknya sebagai ganti dari jumlah aset yang harus dibayarkannya pada negara tentunya menjadi alternatif yang sangat menjanjikan bagi para terpidana, dibandingkan harus mengembalikan aset yang dihasilkannya dari tindak pidana.

Selain pengaturan yang terdapat dalam KUHP dan KUHAP, dalam sistem hukum di Indonesia saat ini telah terdapat ketentuan mengenai perampasan aset dalam UndangUndang Nomor 20 Tahun 2001 tentang Perubahan Undang-Undang Nomor 31 Tahun 1999 tentang Pemberantasan Tindak Pidana Korupsi (UU TIPIKOR). Perampasan aset hasil tindak pidana korupsi merupakan langkah antisipatif dalam menyelamatkan dan atau mencegah harta kekayaan yang diduga berasal dari tipikor agar tidak berpindah tempat maupun berpindah tangan. Secara umum, UU TIPIKOR menggunakan 2 mekanisme dalam melakukan perampasan aset, yaitu mekanisme pidana dan mekanisme perdata.

Mekanisme pidana diatur dalam Pasal 18 ayat (1) huruf (a) UU TIPIKOR, dalam ketentuan tersebut perampasan aset dalam perkara tipikor, diatur sama dengan ketentuan perampasan aset yang berlaku umum yaitu sama dengan ketentuan yang ada dalam KUHAP. Selain mekanisme pidana, UU TIPIKOR juga mengatur mengenai mekanisme perampasan aset secara perdata dalam $\mathrm{Pasal}$ 32 ayat (1). Dalam ketentuan tersebut ketika penyidik menemukan dan berpendapat bahwa sebuah tindak pidana korupsi tidak terdapat cukup bukti, namun ditemukan kerugian negara secara nyata, maka penyidik dapat menyerahkan berkas perkara hasil penyidikan tersebut kepada J aksa Pengacara Negara (JPN) atau instansi yang dirugikan untuk melakukan gugatan secara perdata. S elain itu putusan bebas dalam tindak pidana korupsi juga tidak menghapuskan hak negara untuk mengajukan tuntutan atas kerugian terhadap keuangan negara.

Selain keadaan di atas, terdapat beberapa keadaan yang memungkinkan untuk dilakukan gugatan secara perdata dalam melakukan perampasan aset atas tipikor. Keadaan yang dimaksud adalah: Ketika terdakwa meninggal dunia saat penyidikan sebagaimana diatur di dalam Pasal 33 UU TIPIKOR, dan Pasal 34 UU TIPIKOR yaitu Ketika terdakwa meninggal dunia pada saat dilakukannya pemeriksaan di sidang pengadilan; Ketika putusan pengadilan atas perkara yang dimaksud sudah memiliki kekuatan hukum tetap, dan diketahui bahwa masih terdapat harta benda terpidana yang diduga atau patut diduga berasal dari tindak pidana korupsi dan belum dikenai perampasan oleh negara karena terpidana tidak bisa membuktikan bahwa harta tersebut bukan berasal dari tindak pidana korupsi (Pasal 38 C UU TIPIKOR); Ketika terdakwa meninggal dunia sebelum putusan pengadilan dijatuhkan (Pasal 38 ayat (5) UU TIPIKOR).

Perampasan aset melalui gugatan perdata dengan keadaaan seperti disebutkan di atas, hanya dapat dilakukan ketika kerugian keuangan negara telah secara nyata adanya. Gugatan ini diajukan oleh J PN atau instansi yang dirugikan terhadap terpidana atau ahli warisnya. Dalam hal perampasan aset hasil sitaan terhadap terdakwa yang meninggal dunia tidak dapat dimohonkan upaya banding.

Mekanisme perdata dalam perampasan dilakukan dalam konteks upaya pengembalian asetyang digunakan dalam melakukan tindak pidana korupsi dan atau hasil dari tindak pidana korupsi. Tersedianya mekanisme perdata UU TIPIKOR didasarkan pada penyelesaian perkara korupsi secara pidana tidak selalu berhasil mengembalikan kerugian negara. $\mathrm{Hal}$ tersebut karena terdapat keterbatasan khusus dalam hukum pidana yaitu as et bukan merupakan objek tersendiri dalam hukum pidana. Tersedianya mekanisme perdata dalam perampasan aset hasil tindak pidana 
korupsi bermaksud untuk memaksimalkan pengembalian kerugian negara dalam rangka memenuhi rasa keadilan masyarakat.

Upaya pengembalian kerugian negara yang dikorupsi melalui perampasan aset secara perdata diarahkan pada dua sumber, yaitu hasil korupsi yang telah menjadi bagian dari kekayaan terdakwa atau terpidana, dan penggantian kerugian dari kekayaan terpidana, terdakwa, tersangka walaupun hasil korupsi tidak dimilikinya. Dalam hal ini korupsi yang dilakukan tidak menguntungkan terdakwa, pihak yang diuntungkan dengan terjadinya korupsi yang dimaksud menguntungkan orang lain atau suatu korporasi (https:// gagasanhukum.wordpress.com/2008/09/01/ prinsip-pengembalian-aset-hasil-korupsibagian-ii).

Gugatan perdata dalam rangka perampasan aset hasil tipikor, memiliki karakter yang spesifik, yaitu hanya dapat dilakukan ketika upaya pidana tidak lagi memungkinkan untuk digunakan dalam upaya pengembalian kerugian negara pada kas negara. Keadaan dimana pidana tidak dapat digunakan lagi antara lain tidak ditemukan cukup bukti; meninggal dunianya tersangka, terdakwa, terpidana; terdakwa diputus bebas; adanya dugaan bahwa terdapat hasil korupsi yang belum dirampas untuk negara walaupun putusan pengadilan telah berkekuatan hukum tetap. Dengan adanya pengaturan gugatan perdata untuk perampasan aset dalam Pasal 32, 33, 34, 38C UU TIPIKOR, dapat disimpulkan bahwa tanpa adanya pengaturan tersebut maka perampasan aset hasil tindak pidana korupsi dengan menggunakan mekanisme perdata tidak dapat dilakukan. Perampasan aset dengan menggunakan mekanisme pidana dalam UU TIPIKOR dan KUHP serta KUHAP pada dasarnya tidak memiliki perbedaan secara mendasar, karena samasama menunggu putusan pengadilan yang berkekuatan hukum mengikat, membutuhkan waktu yang lama dan tidak maksimal dalam upaya pengembalian kerugian negara yang dikorupsi.

Tersedianya mekanisme perdata dalam perampasan aset hasil tindak pidana korupsi, dapat menjawab kekurangan yang dimiliki oleh mekanisme pidana antara lain tetap dapat melakukan gugatan walaupun tersangka, terdakwa, ataupun terpidana meninggal dunia sehingga dapat meningkatkan upaya pengembalian kerugian negara yang dikorupsi. Namun di sisi lain tersedianya mekanisme perdata dalam upaya perampasan aset hasil tindak pidana korupsi seperti yang terdapat dalam UU TIPIKOR juga belum maksimal karena proses perdata menganut sistem pembuktian formil yang dalam prakteknya bisa lebih sulit daripada pembuktikan materiil. Dengan demikian penerapan perampasan aset berdasarkan UU TIPIKOR belum berhasil secara maksimal untuk mengembalikan kerugian keuangan negara sehingga diperlukan suatu alternatif kebijakan hukum dalam upaya pengembalian kerugian keuangan negara, antara lain pengadopsian ketentuan perampasan aset tanpa tuntutan pidana sesuai dengan Konvensi PBB Anti Korupsi Tahun 2003 dengan melakukan beberapa penyesuaian dengan kondisi yang ada dalam sistem hukum di Indonesia.

Menurut Mulder, salah satu dimensi dalam kebijakan hukum pidana adalah seberapa jauh kebijakan hukum pidana yang berlaku perlu diubah/diperbarui. Berdasarkan penjelasan sebelumnya, terlihat bahwa Indonesia telah memiliki pengaturan tersendiri mengenai perampasan aset secara umum yang terdapat dalam KUHAP, dan perampasan asetsecara khusus seperti yang diatur bagi tindak pidana korupsi. Namun, ketentuan hukum yang ada dirasakan belum cukup memadai bagi upaya perampasan aset hasil tindak pidana yang dikuasai oleh pelaku tindak pidana. Sebab tidak cukup efektif guna melakukan perampasan aset hasil tindak pidana, sehingga aset hasil tindak pidana yang berhasil dirampas belum maksimal.

Selain mekanisme pidana, disediakan juga mekanisme perdata dalam UU TIPIKOR, sayangnya karena terdapatdalamUU TIPIKOR objek pengaturan dalam perampasan aset menggunakan mekanisme perdata hanya terbatas pada tindak pidana korupsi saja. $P$ ada tindak pidana lain yang terdapat unsur ekonomi di dalamnya belum dapat dilakukan perampasan aset dengan menggunakan mekanisme perdata karena belum ada peraturan tertulis yang mengaturnya, kecuali menempuh jalur perdata sendiri setelah perkara pidana incracht.

Menurut penulis, hal ini menunjukkan bahwa perlu dilakukan perubahan atas 
kebijakan hukum perampasan aset di Indonesia, sehingga hal-hal yang disebutkan diatas tidak lagi menjadi hambatan dalam upaya perampasan aset di Indonesia. Berdasarkan dimensi pertama dalamm kebijakan hukum pidana menurut Mulder, maka metode perampasan aset yang berlaku dalam sistem hukum di Indonesia perlu mengalami perubahan. Perubahan tersebut dapat dilakukan dengan melakukan perubahan sistem perampasan aset sehingga dapat dicapai hasil yang maksimal atas upaya perampasan aset hasil tindak pidana di Indonesia.

Perubahan metode tersebut sangat penting mengingat dengan adanya metode perampasan aset yang efektif, maka diharapkan angka terjadinya tindak pidana dapat ditekan dan kerugian yang ditimbulkan oleh sebuah tindak pidana dapat dikembalikan pada pihak yang berhak. Perubahan metode tersebut harus dapat menjadi jawaban bagi kelemahan peraturan hukum tentang perampasan aset yang berlaku di dalam sistem hukum di Indonesia saat ini, yaitu memerlukan waktu penyelesaian yang lama, mekanisme penyitaan yang sangat kaku, paradigma penyelesaian perkara hanya pada pelaku, dan tersedianya metode subsider.

Berdasarkan uraian di atas maka dalam hal ini perlu segera diundangkan RUU Perampasan Aset yang didalamnya terdapat ketentuan mengenai metode perampasan aset yang lebih efektif daripada yang ada sekarang dengan menggunakan perampasan aset in rem atau yang sering pula dikenal sebagai Non-Conviction Based Asset Forfeiture atau yang sering disebut NCB.

Salah satu latar belakang dari perlunya diadakan Undang-undang P erampasan Aset yang saat ini masih berbentuk RUU adalah ratifikasi United Nation Convention Against Corruption, 2003 (UNCAC) oleh Indonesia dilakukan melalui Undang-Undang Nomor 7 Tahun 2006 tentang Pengesahan United Nation Convention Against Corruption, 2003 (Konvensi Perserikatan Bangsa-Bangsa Anti Korupsi, 2003). Salah satu bagian penting yang diatur dalam UNCAC adalah adanya pengaturan yang berkaitan dengan penelusuran, penyitaan, dan perampasan hasil dan instrumen tindak pidana antar negara. Sebagai konsekuensi dari ratifikasi tersebut maka pemerintah Indonesia harus menyesuaikan ketentuan-ketentuan perundang-undangan yang ada dengan ketentuan-ketentuan yang ada di dalam konvensi tersebut, sehingga Indonesia dapat melakukan upaya perampasan aset hasil tindak pidana khususnya hasil korupsi secara maksimal.

Di dalam UNCAC terdapat ketentuan yang detail mengenai mekanisme perampasan aset hasil tindak pidana dengan menggunakan metode Non-Conviction Based Asset Forfeiture, sehingga dapat menjadi acuan untuk negara pihak dalam melakukan kerjasama internasional dalam permasalahan kejahatan maupun keuangan serta penggunaan teknologi antara sesama dalam upaya perampasan aset hasil tindak pidana korupsi.

UNCAC menentukan bahwa semua negara pihak wajib untuk mempertimbangkan perampasan hasil tindak kejahatan tanpa melalui pemidanaan (NCB). Dalam hal ini UNCAC tidak memandang adanya perbedaan sistem hukum di antara negara pihak, NCB dianggap sebagai suatu sistem yang dapat melampaui perbedaan-perbedaan antar sistem hukum yang dianut oleh para negara pihak dari UNCAC. UNCAC mengusulkan NCB sebagai alat untuk semua yurisdiksi dalam upaya pemberantasan tindak pidana korupsi.

Dengan menjadi negara peratifikasi, maka Indonesia harus tunduk pada ketentuan yang ada dalam UNCAC. Setelah melakukan ratifikasi seharusnya Indonesia juga melakukan penyesuaian ketentuan hukum yang berlaku di Indonesia dengan UNCAC selaku konvensi internasional dimana Indonesia menjadi bagian di dalamnya. Hadirnya Rancangan Undang-Undang Perampasan Aset menjadi salah satu langkah dari pemerintah Indonesia dalam melakukan tindak lanjut atas ratifikasi terhadap UNCAC. Hal tersebut karena dengan adanya Rancangan Undang-Undang perampasan aset yang menganut mekanisme perampasan pidana in rem (NCB) Indonesia telah melakukan penyesuaian dengan ketentuan yang ada dalam UNCAC selaku konvensi internasional.

\section{Simpulan}

1. Perampasan asset dengan model NonConviction Based Asset Forfeiture diperlukan 
dalam rangka pengembalian aset hasil tindak pidana korupsi yang lebih efektif, oleh karena sesuai dengan follow the money atau follow the asset serta melaksanakan mandat dari UNCAC selaku negara peratifikasi.

2. Model yang ideal dalam perampasan aset tindak pidana korupsi adalah dengan menggunakan mekanisme hukum baru dengan penerapan Non-Conviction Based Asset Forfeiture, dan menggunakan pembuktian delik materiil, berbeda dengan delik formil yang saat ini digunakan di dalam Undang-undang Tindak Pidana Korupsi.

\section{E. Saran}

1. Bagi legislatif perlu segera mengkaji dan membahas RUU Perampasan Aset dan segera mengesahkannya.

2. Bagi penegak hukum hendaknya berorientasi pada follow the assetdi dalam pemberantasan tindak pidana korupsi.

\section{Daftar Pustaka}

Agus Santoso, Wakil P PATK dalam J urnal "P eran Aktif Perbankan Dalam Mewujudkan Negara YangBersih Dari KKN", Makalah Seminar dan Pembekalan Kompetisi Peradilan Semu, Nasional Mutiara Djokosoetono VIII, Fakultas Hukum Indonesia, J akarta, 6 A pril 2014.

Asep Warlan Yusuf, J urnal "Penegakan Hukum Dalam Tindak Pidana Korupsi (Perpektif Hukum Administrasi)", Makalah, S eminar O ptimalisasi Kewenangan Kejaksaan Dalam Pengembalian Aset Hasil Korupsi Melalui Instrumen Hukum Perdata, Hotel G rand Aquila, Bandung, 26 O ktober 2013.

E ka Iskandar, "P rinsip Pengembalian Aset Hasil Korupsi". Artikel hukum, http://gagasanhukumwordpress. com/2008/09/01/prinsip-pengemba lian-aset-hasil-korupsi-bagian-ii/S eptember 2008.

Harkristuti Harkrisnowo, "Kriminalisasi P emutihan Uang (Money Laundering)" sebagai bagian dari White Collar Crime, (Makalah disampaikan pada seminar Money Laundering (Pencucian Uang) Ditinjau dari Perspektif Hukum dan Ekonomi, J akarta, 23 Agustus 2001), diakses tanggal 31 Agustus 2016 pukul 09.07 WIB.

http://www.bedanews.com/prof-dr-h-dwidja-priyatno-usulkan-amandemen uuptpk, diakses 31 Agustus 2016 Pukul 09.00 WIB.

http://www.bedanews.com/prof-dr-h-dwidja-priyatno-usulkan-amandemen-uuptpk, diakses tanggal 31 Agustus 2016 Pukul 09.11 WIB.

http://www.kejaksaan.go.id/unit_kejaksaan.php? idu=2\&sm=3, diakses pada tanggal 31 Agustus 2016.

http://nasional.kompas.com/read/2016/01/27/15053181/Indeks.Persepsi.Korupsi.Indonesia. Membaik, diakses pada tanggal 16 September 2016 pukul 16.30 WIB.

Indiyanto Seno Adji, 2007, Kebijakan A paratur Negara dan Hukum Pidana, Diedit Media, J akarta.

Romli Atmasasmita, 2006, "Strategi dan Kebijakan Pemberantasan Korupsi Pasca Konvensi PBB Menentang Korupsi Tahun 2003 : Melawan Kejahatan Korporasi," Makalah, Seminar, J akarta.

Romli Atmasasmita, "Urgensi RUU Pengembalian Aset", dalam https://korup 5170.wordpress.com/ opiniartikelpakarhukum/urgensi-ruu-pengemba lian-aset, diakses pada tanggal 31 Agustus 2016 pukul 09.30 WIB.

Romli Atmasasmita, 2010, Globalisasi Dan Kejahatan Bisnis, Kencana, J akarta.

ST. Burhanuddin, "J aksa Agung Muda P erdata dan Tata Usaha Negara, J urnal O ptimalisasi Kewenangan Kejaksaan Dalam P engembalian Aset Hasil Korupsi Melalui Instrumen Hukum Perdata", Makalah Seminar, Hotel Grand Aquila, Bandung, 26 Oktober 2013.

Sulistyowati Irianto dan Shidarta, 2013, Metode Penelitian Hukum; Konstelasi dan Refleksi, Yayasan Pustaka Obor, J akarta. 
.J urnal Pasca Sarjana Hukum UNS Vol V No. 1 J anuari-J uni 2017

Yenti Garnasih, 2010, "Asset RecoveryActs ebagai strategi dalam pengembalian asethasil korupsi, dalam Perampasan Aset Hasil Tindak P idana," J urnal Legislasi Indonesia, Vol.7 No.4, Desember 2010.

Yunus Husein, 2010, "Perampasan Aset Hasil Tindak Pidana di Indonesia yang mengacu pada Pasal 10 KUHP huruf b tentang pidana tambahan", J urnal Legislasi Indonesia, Vol.7 No.4, Desember 2010, diakses pada tanggal 31 Agustus 2016 pukul 09.20 WIB. 